\title{
CORRECTION
}

\section{Correction to: The Effect of a Change Agent on Use of Evidence-Based Mental Health Practices}

\author{
Sonya J. Leathers ${ }^{1} \cdot$ Jill E. Spielfogel ${ }^{1,3} \cdot$ Joan Blakey ${ }^{1,4} \cdot$ Errick Christian $^{1,5} \cdot$ Marc S. Atkins $^{2}$
}

Published online: 24 February 2018

(c) Springer Science+Business Media, LLC, part of Springer Nature 2018

\section{Correction to: \\ Administration and Policy in Mental Health and Mental Health Services Research (2016) 43:768-782 https://doi.org/10.1007/s10488-015-0694-1}

The original version of this article unfortunately contained a mistake. Table 1 was incorrect in the original version of this article.

The corrected Table 1 is given below.
Table 1 Provider demographics $(N=56)$

\begin{tabular}{|c|c|c|c|}
\hline Variable & $M$ & $S D$ & $\%$ \\
\hline Age & 33.46 & 7.76 & \\
\hline Female & & & 80 \\
\hline \multicolumn{4}{|l|}{ Race } \\
\hline African American & & & 46 \\
\hline White & & & 46 \\
\hline Asian & & & 5 \\
\hline Other & & & 2 \\
\hline \multicolumn{4}{|l|}{ Degree } \\
\hline Bachelors & & & 36 \\
\hline Masters & & & 57 \\
\hline Not reported & & & 7 \\
\hline \multicolumn{4}{|l|}{ Position } \\
\hline Case Manager & & & 75 \\
\hline Therapist & & & 25 \\
\hline
\end{tabular}

Note Demographic data were missing for one provider

The original article can be found online at https://doi.org/10.1007/ s10488-015-0694-1.

Sonya J. Leathers

sonyal@uic.edu

1 Jane Addams College of Social Work, University of Illinois at Chicago, 1040 W. Harrison St., Chicago, IL 60607-7134, USA

2 Department of Psychiatry, University of Illinois at Chicago, Chicago, IL, USA

3 Present Address: School of Social Service Administration, University of Chicago, Chicago, IL, USA

4 Present Address: Helen Bader School of Social Welfare, University of Wisconsin at Milwaukee, Milwaukee, WI, USA

5 Present Address: Department of Emergency Medicine, University of Illinois at Chicago, Chicago, IL, USA 